\title{
Insomnia as a predisposing factor for medical conditions
}

\author{
Ana Maria Alexandra Stanescu' ${ }^{1}$ Oana Nicolescu', Alexandru Mihai Stefanescu², \\ Gabriela Carmen Obilisteanu' ${ }^{2}$ Cristian Gabriel Bejan' ${ }^{1}$ Anca Angela Simionescu ${ }^{3,4}$ \\ ${ }^{1}$ Department of Family Medicine, "Carol Davila" University of Medicine and Pharmacy, Bucharest, Romania \\ 2"Nicolae Malaxa" Clinical Hospital, Bucharest, Romania \\ ${ }^{3}$ Department of Obstetrics and Gynecology, "Carol Davila" University of Medicine and Pharmacy, \\ Bucharest, Romania \\ ${ }^{4}$ Filantropia Clinical Hospital, Bucharest, Romania
}

\begin{abstract}
An essential aspect of human health is sleep. Sleep, among others, interacts with the immune system, plays a role in restoring the body's energy, healing and brain function. Insomnia is often noticed in medical practice, is considered a public health problem. Acute sleep deprivation can alter cognitive performance, and chronic sleep deprivation can lead to disease development. Lack of sleep affects all major systems in the human body, and the major changes that occur in chronic insomnia have been associated with many conditions such as type 2 diabetes, cardiovascular disease, asthma, thyroid disease and gastroesophageal reflux disease.
\end{abstract}

Keywords: insomnia, sleep, medical conditions

\section{INTRODUCTION}

An essential aspect of human health is sleep. Sleep, among others, interacts with the immune system, plays a role in restoring the body's energy, healing and brain function (1). Acute sleep deprivation can alter cognitive performance, and chronic sleep deprivation can lead to disease development (2). Insomnia is often noticed in medical practice, is considered a public health problem.

Difficulties in initiating sleep represent sleep disturbance, difficulties in maintaining sleep, low quality of sleep, followed by low functioning during the day (3). In adults, $33-50 \%$ have frequent signs of insomnia, with a prevalence of $10-15 \%$ in the general population, with a higher frequency in women and the elderly $(4,5)$. Along with chronic sleep disorders increases the risk of anxiety, suicide, depression, risk of accidents. Although initially considered a symptom, insomnia is now considered a disorder.

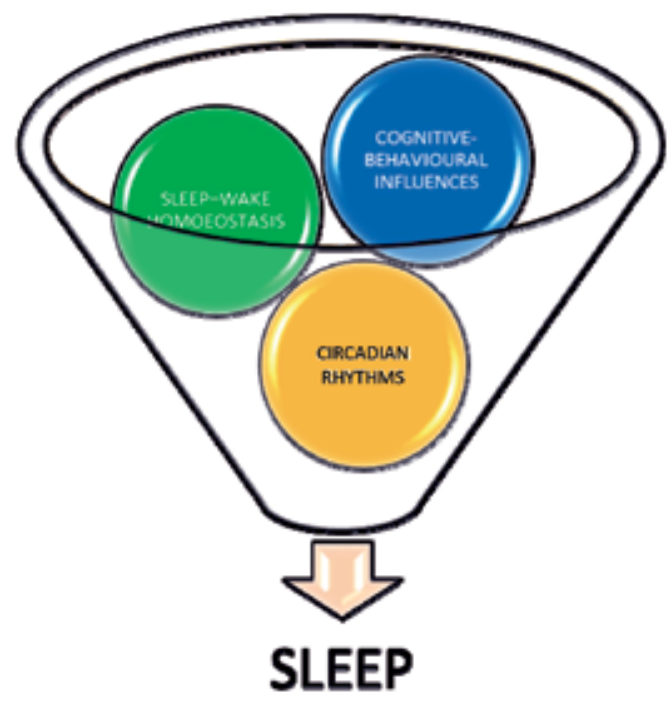

FIGURE 1. The essential factors that regulate sleep

At the genetic level, the genes associated with insomnia are apolipoprotein E4, period circadian regulator 3 , clock circadian regulator and 5 seroto- 
nin transporter linked polymorphic region genes, being also a close association between insomnia and HLA-DQB1 * 0602 (6).

TABLE 1. International classification of sleep disorders (7)

\begin{tabular}{|l|l|}
\hline $\begin{array}{l}\text { Chronic insomnia } \\
\text { disorder }\end{array}$ & $\begin{array}{l}\text { Sleep disturbances for the last three } \\
\text { months affecting nighttime sleep at least } \\
\text { three times a week. }\end{array}$ \\
\hline $\begin{array}{l}\text { Short-term } \\
\text { insomnia disorder }\end{array}$ & $\begin{array}{l}\text { Sleep disturbances experienced within } \\
\text { three months. }\end{array}$ \\
\hline $\begin{array}{l}\text { Other insomnia } \\
\text { disorder }\end{array}$ & $\begin{array}{l}\text { Sleep disturbances that do not meet the } \\
\text { criteria for chronic insomnia or short- } \\
\text { term insomnia disorder. }\end{array}$ \\
\hline
\end{tabular}

Behavioral determinants and poor sleep quality were associated with stress, anxiety, smoking, alcohol consumption, increased sugar consumption, workplace pressures, regular work schedule, physical activity, regular sleep and travel time (8). The associations between diet, physical activity and sleep are bidirectional.

TABLE 2. Subtypes of insomnia (7)

\begin{tabular}{|l|l|}
\hline $\begin{array}{l}\text { Psychophysiological } \\
\text { insomnia }\end{array}$ & $\begin{array}{l}\text { Increased levels of cognitive and } \\
\text { somatic arousal at bedtime }\end{array}$ \\
\hline Idiopathic insomnia & $\begin{array}{l}\text { Sleep disturbances occurring early } \\
\text { in childhood and persisting over a } \\
\text { lifelong period. }\end{array}$ \\
\hline Paradoxical insomnia & $\begin{array}{l}\text { The patients underestimate the total } \\
\text { amount of sleep they obtained. }\end{array}$ \\
\hline $\begin{array}{l}\text { Inadequate sleep } \\
\text { hygiene }\end{array}$ & $\begin{array}{l}\text { Sleep hygiene highlights the effect of } \\
\text { of chily activity on the quality of sleep. }\end{array}$ \\
\hline inood & $\begin{array}{l}\text { In children may be affected by their } \\
\text { dependency on certain stimulations, } \\
\text { objects, environmental settings, } \\
\text { disruption of which can significantly } \\
\text { delay falling asleep or may show } \\
\text { resistance to go to bed or both. }\end{array}$ \\
\hline
\end{tabular}

Chronic sleep changes have been associated with many conditions such as obesity, diabetes and neuropsychiatric disorders.

\section{THE RELATIONSHIP BETWEEN INSOMNIA AND OTHER CONDITIONS}

\section{Type 2 diabetes mellitus}

Chronic insomnia increases by $16 \%$ the risk of developing type 2 diabetes in adults, and the duration of insomnia is proportional to the risk of developing type 2 diabetes $(9,10)$. Several mechanisms contribute to pathogenesis, such as disorder of the hypothalamic-pituitary axis with an increase in cortisol levels, impaired glucose metabolism, imbalance in the leptin-ghrelin system that increases appetite and the risk of obesity causing insulin resistance and unstable blood sugar (11).

\section{Asthma}

Chronic insomnia increases the risk of developing asthma and allergic rhinitis, having as a possible mechanism the release of inflammatory mediators such as interleukin 6, the cellular kappa-B nuclear factor in chronic insomnia resulting in allergic airway inflammation (12-14). Epithelial inflammation of the airways in chronic insomnia may be caused by reduced production of interferon- $\gamma$, increasing the risk of reactive airway disease.

\section{Cardiovascular disease}

Cardiovascular morbidity and mortality may be higher in people with insomnia due to the hypothalamic-pituitary axis's disorders with increased release of the hormone adrenocorticotropin, increased sympathetic nervous system activity, increased inflammatory cytokines and increased levels of C-reactive proteins $(15,16)$. In patients with insomnia, the risk of myocardial infarction increases by $27-45 \%$ and also increases the risk of hypertension $(17,18)$.

\section{Gastroesophageal reflux disease}

There is a two-way association between gastroesophageal reflux disease and insomnia, with gastroesophageal reflux disease having negative effects on sleep (19). Mody et al. reported that people with gastroesophageal reflux disease reported $88.9 \%$ sleep disorders and $49.1 \%$ difficulty maintaining sleep (20). Proton pump inhibitors, a treatment used in gastroesophageal reflux disease, improve sleep disorders (21). It increases three times the risk of developing insomnia in patients with esophageal reflux disease (22).

\section{Thyroid disorders}

Disorder in the hypothalamic-pituitary axis in chronic insomnia increases the level of corticotropin-releasing hormone, thyrotropin-releasing hormone and cortisol, resulting in fluctuations in thyroid hormone levels (23).

\section{CONCLUSIONS}

Lack of sleep affects all major systems in the human body, and the major changes that occur in chronic insomnia have been associated with many conditions such as type 2 diabetes, cardiovascular disease, asthma, thyroid disease and gastroesophageal reflux disease. Several studies are necessary to determine precisely all the diseases that can be caused by insomnia and the concrete mechanism. 


\section{REFERENCES}

1. Imeri L, Opp MR. How (and why) the immune system makes us sleep. Nat Rev Neurosci. 2009;10(3):199-210.

2. Bertisch SM, Pollock BD, Mittleman MA, Buysse DJ, Bazzano LA, Gottlieb DJ, Redline S. Insomnia with objective short sleep duration and risk of incident cardiovascular disease and all-cause mortality: Sleep Heart Health Study. Sleep. 2018 Jun 1;41(6):zsy047.

3. Mellinger GD, Balter MB, Uhlenhuth EH. Insomnia and its treatment. Prevalence and correlates. Arch Gen Psychiatry. 1985 Mar;42(3):225-32.

4. Ancoli-Israel S, Roth T. Characteristics of insomnia in the United States: results of the 1991 National Sleep Foundation Survey. I. Sleep. 1999 May 1;22 Suppl 2:S347-53.

5. Dollander M. Etiologies de l'insomnie chez l'adulte [Etiology of adult insomnia]. Encephale. 2002 Nov-Dec;28(6 Pt 1):493-502.

6. Bollu PC, Kaur H. Sleep Medicine: Insomnia and Sleep. Mo Med. 2019;116(1):68-75.

7. Sateia MJ. International classification of sleep disorders-third edition: highlights and modifications. Chest. 2014 Nov;146(5):1387-1394.

8. Taheri S. The link between short sleep duration and obesity: we should recommend more sleep to prevent obesity. Arch Dis Child. 2006;91(11):881-884.

9. Kawakami N, Takatsuka N, Shimizu H. Sleep disturbance and onset of type 2 diabetes. Diabetes Care. 2004 Jan;27(1):282-283.

10. Lin CL, Chien WC, Chung CH, Wu FL. Risk of type 2 diabetes in patients with insomnia: A population-based historical cohort study. Diabetes Metab Res Rev. 2018 Jan;34(1).

11. Spiegel K, Tasali E, Penev P, Van Cauter E. Brief communication: Sleep curtailment in healthy young men is associated with decreased leptin levels, elevated ghrelin levels, and increased hunger and appetite. Ann Intern Med. 2004 Dec 7;141(11):846-850.

12. Lin $Y$, Lai $C$, Chien $C$, et al. Is insomnia a risk factor for new-onset asthma? A population-based study in Taiwan. BMJ Open. 2017;7:e018714

13. Ather JL, Hodgkins SR, Janssen-Heininger YM, Poynter ME. Airway epithelial NF-KB activation promotes allergic sensitization to an innocuous inhaled antigen. Am J Respir Cell Mol Biol. 2011;44(5):631-638.

\section{Conflict of interest: none declared} Financial support: none declared
14. Neveu WA, Allard JL, Raymond DM, Bourassa LM, Burns SM, Bunn JY, Irvin CG, Kaminsky DA, Rincon M. Elevation of IL-6 in the allergic asthmatic airway is independent of inflammation but associates with loss of central airway function. Respir Res. 2010 Mar 8;11(1):28.

15. Javaheri S, Redline S. Insomnia and Risk of Cardiovascular Disease. Chest. 2017 Aug;152(2):435-444.

16. Castro-Diehl C, Diez Roux AV, Redline S, Seeman T, Shrager SE, Shea S. Association of Sleep Duration and Quality With Alterations in the Hypothalamic-Pituitary Adrenocortical Axis: The Multi-Ethnic Study of Atherosclerosis (MESA). J Clin Endocrinol Metab. 2015 Aug;100(8):3149-3158.

17. Vgontzas AN, Liao D, Bixler EO, Chrousos GP, Vela-Bueno A. Insomnia with objective short sleep duration is associated with a high risk for hypertension. Sleep. 2009 Apr;32(4):491-497.

18. Krokstad S, Langhammer A, Hveem K, Holmen TL, Midthjell K, Stene TR, Bratberg G, Heggland J, Holmen J. Cohort Profile: the HUNT Study, Norway. Int J Epidemiol. 2013 Aug;42(4):968-977.

19. Stein E, Katz PO. GERD: GERD and insomnia-first degree relatives or distant cousins? Nat Rev Gastroenterol Hepatol. 2010 Jan;7(1):810.

20. Mody R, Bolge SC, Kannan H, Fass R. Effects of gastroesophageal reflux disease on sleep and outcomes. Clin Gastroenterol Hepatol. 2009 Sep;7(9):953-959.

21. Johnson DA, Orr WC, Crawley JA, Traxler B, McCullough J, Brown $\mathrm{KA}$, Roth T. Effect of esomeprazole on nighttime heartburn and sleep quality in patients with GERD: a randomized, placebo-controlled trial. Am J Gastroenterol. 2005 Sep;100(9):1914-1922.

22. Jansson $C$, Nordenstedt $H$, Wallander MA, Johansson $S$, Johnsen $R$, Hveem K, Lagergren J. A population-based study showing an association between gastroesophageal reflux disease and sleep problems. Clin Gastroenterol Hepatol. 2009 Sep;7(9):960-5.

23. Xia L, Chen GH, Li ZH, Jiang S, Shen J. Alterations in hypothalamuspituitary-adrenal/thyroid axes and gonadotropin-releasing hormone in the patients with primary insomnia: a clinical research. PLoS One. 2013 Aug 9;8(8):e71065. 